\title{
Zinc absorption in adult men from a chicken sandwich made with white or wholemeal bread, measured by a double-label stable-isotope technique
}

\author{
BY SUSAN J. FAIR WEATHER-TAIT*, THOMAS E. FOX, \\ S. GABRIELLE WHARF, JOHN EAGLES AND HUGH KENNEDY† \\ AFRC Institute of Food Research, Norwich Research Park, Colney, Norwich NRI 3SR
}

(Received 25 October 1990-Accepted 28 June 199I)

\begin{abstract}
Eleven fasted adult men consumed a chicken meat sandwich made with white or wholemeal bread, extrinsically labelled with $2 \mathrm{mg}{ }^{67} \mathrm{Zn}$, on two different occasions. Immediately after eating the sandwich they were given an intravenous injection of $1.5 \mathrm{mg}{ }^{70} \mathrm{Zn}$. True $\mathrm{Zn}$ absorption (which was approximately $7 \%$ higher than apparent absorption) was determined by the faecal balance technique by making an allowance for endogenous excretion from measurements of faecal excretion of ${ }^{70} \mathrm{Zn}$. There was no significant difference in mean true $\mathrm{Zn}$ absorption from the white or wholemeal bread sandwich, 33.6 and $\mathbf{2 5 . 4} \%$ respectively. It was concluded that the substitution of wholemeal for white bread does not reduce $\mathrm{Zn}$ absorption from meat-based sandwiches.
\end{abstract}

Zinc absorption: Chicken meat: Bread: Stable isotope

The amount of zinc that is available for absorption from a meal depends on the chemical composition of its constituent foods. There are a number of known inhibitors of $\mathrm{Zn}$ absorption of which phytate (myo-inositol hexaphosphate) is probably the most biologically significant. Phytate is the principal storage form of phosphorus in plants, concentrated in the aleurone layer of cereals, but animals products contain little or no phytate. This is one of the reasons why diets high in cereals but low in animal protein contain $\mathrm{Zn}$ of lower bioavailability (Navert et al. 1985).

Current dietary guidelines for developed countries emphasize an increased intake of complex carbohydrates. Many consumers have responded to these recommendations by replacing white bread by wholemeal bread. The precise effects of such a change on $\mathrm{Zn}$ bioavailability are not known, although there are indications that a moderate increase in complex carbohydrates has a minimal effect on Zn nutrition (Mason et al. 1990). The aim of the present study was to determine the precise effect of consuming wholemeal instead of white bread on $\mathrm{Zn}$ absorption from a chicken-meat sandwich.

\section{METHODS}

Subjects and diets

Eleven men between 20 and 54 (mean 34) years of age volunteered for the study. They all appeared to be in good health, and reported no history of gastrointestinal dysfunction. Measurements of height and weight (Table 1) were within normally accepted limits. For the duration of the study, in order to prevent any major changes in $\mathrm{Zn}$ metabolism and homeostasis, each subject was asked to maintain his usual dietary pattern using a self-

\footnotetext{
* For reprints.

+ Present address: West Norwich Hospital, Bowthorpe Road, Norwich NRI 3SR
} 
Table 1. Details of subjects studied: age (years) height $(\mathrm{m})$, weight $(\mathrm{kg})$ and mean daily zinc intake $(m g / d)$

\begin{tabular}{|c|c|c|c|c|c|c|}
\hline \multirow[b]{2}{*}{ Subject no. } & \multirow[b]{2}{*}{ Age } & \multirow[b]{2}{*}{ Height } & \multicolumn{3}{|c|}{$\begin{array}{l}\text { Analysed mean } \\
\mathrm{Zn} \text { intake }\end{array}$} & \multirow{2}{*}{$\begin{array}{l}\text { Calculated } \\
\text { mean } \mathrm{Zn} \text { intake }\end{array}$} \\
\hline & & & $\mathrm{Wt}$ & Mean & SD & \\
\hline 1 & 41 & 1.928 & $67 \cdot 2$ & $* 10.5$ & $3 \cdot 5$ & $+11 \cdot 3$ \\
\hline 2 & 22 & 1.711 & 706 & $* 9.9$ & 3.4 & $\dagger 11 \cdot 6$ \\
\hline 3 & 20 & 1.747 & $72 \cdot 6$ & $* 5.4$ & 1.5 & +6.1 \\
\hline 4 & 26 & 1.755 & $74 \cdot 8$ & $* 7.4$ & 3.5 & $+8 \cdot 1$ \\
\hline 5 & 28 & $1 \cdot 800$ & $87 \cdot 3$ & $+6 \cdot 3$ & $2 \cdot 0$ & $* 5.4$ \\
\hline 6 & 52 & $1 \cdot 822$ & $81 \cdot 4$ & +11.9 & $2 \cdot 0$ & $* 10.5$ \\
\hline 7 & 32 & 1.710 & $67 \cdot 5$ & $+9 \cdot 1$ & 1.5 & $* 7.9$ \\
\hline 8 & 54 & 1.680 & $78 \cdot 5$ & +6.9 & $4 \cdot 5$ & $* 6.0$ \\
\hline 9 & 24 & 1.799 & $66 \cdot 7$ & $* 13.8$ & 3.9 & $+15 \cdot 0$ \\
\hline 10 & 52 & 1.657 & $63 \cdot 5$ & +6.6 & $2 \cdot 3$ & $* 5 \cdot 1$ \\
\hline 11 & 23 & 1.846 & $71 \cdot 8$ & $* 9 \cdot 6$ & $3 \cdot 1$ & Not available \\
\hline Mean & 34 & 1.769 & $72 \cdot 9$ & 8.9 & & \\
\hline $\mathrm{SD}$ & 13 & 0.080 & $7 \cdot 1$ & $2 \cdot 6$ & & \\
\hline
\end{tabular}

selected $7 \mathrm{~d}$ rotating cycle. This was considered to be a more important feature of the experimental design than inter-subject differences in $\mathrm{Zn}$ intake because each subject acted as his own control. However, one change to the habitual diet was made over the period of study, namely the type of bread eaten; subjects were told to consume white bread during the week before the white-bread test meal, and wholemeal bread during the week before the wholemeal-bread test, thus allowing a period of adaptation. Each subject was asked to weigh and record all food and drinks for the $7 \mathrm{~d}$ period preceding the first test meal. The $7 \mathrm{~d}$ menu was consumed the week leading up to and following each test meal. In order to measure $\mathrm{Zn}$ intakes accurately, a $7 \mathrm{~d}$ duplicate diet collection was made during the week of the second test meal. The subjects were given written information about the study which had been approved by the Institute of Food Research Ethics Committee.

\section{Preparation and administration of test meals}

Chicken meat was prepared for another study using rats (Fairweather-Tait et al. 1991). It was labelled intrinsically with the stable isotope ${ }^{67} \mathrm{Zn}$ by injecting the brachial vein in alternate wings of ten Ross I broiler-type cockerels (mean weight $2.025 \mathrm{~kg}$ ) with $1 \mathrm{ml}$ of a solution of ${ }^{67} \mathrm{Zn}\left(1.84 \mathrm{mg}{ }^{67} \mathrm{Zn} / \mathrm{ml}\right.$ ) daily for $5 \mathrm{~d}$ (Fox et al. 1991). After 1 week the birds were killed, bled, defeathered and eviscerated. The skin and bone were removed and the breast and leg meat cooked in a microwave oven at $400 \mathrm{~W}$ for $10 \mathrm{~min}$. The leached juices were discarded and the cooked meat was minced in a food blender (Magimix, Godalming, Surrey) and stored at $-18^{\circ}$ until use. On analysis it was found that the chicken meat was not sufficiently enriched with ${ }^{67} \mathrm{Zn}$ to provide enough ${ }^{67} \mathrm{Zn}$-labelled meat in one meal for absorption to be measured by faecal balance. Therefore, an additional $2.106 \mathrm{mg}{ }^{67} \mathrm{Zn}$ (as zinc chloride in distilled water) was consumed with each test meal as an extrinsic label.

The day before the test meal the meat was defrosted and weighed portions were made into sandwiches with wholemeal or white bread spread with margarine (Flora; Van den Berghs \& Jurgens, Sussex). After an overnight fast the subjects were given accurately 
weighed quantities of sandwiches made from a mean of 125 (SD 7) g bread, 23 (SD 3) g margarine and 104 (SD 9) g chicken meat. Each subject received both wholemeal and white sandwiches, in random order, 1 week or more apart. Malvern water was allowed ad lib. with the meal.

Radio-opaque markers were taken with the meal to check on the completeness of the subsequent faecal collection (Fairweather-Tait et al. 1989 b). No food or drink was allowed for $4 \mathrm{~h}$, after which time the subjects returned to their habitual diet. Carmine (500 $\mathrm{mg}$ ) was taken in two capsules with the evening meal.

In addition to measuring apparent absorption of $\mathrm{Zn}$ from the test meals, an attempt was made to estimate endogenous excretion of $\mathrm{Zn}$ so as to correct the apparent absorption value to calculate true absorption. The method employed was analogous to that used for calcium (Fairweather-Tait et al. 1989 a). Each subject was given an intravenous injection of $1.5 \mathrm{mg}{ }^{70} \mathrm{Zn}$ immediately after consuming the first ${ }^{67} \mathrm{Zn}$-labelled test meal, and faecal and urinary excretion of the ${ }^{70} \mathrm{Zn}$ was measured as an index of endogenous $\mathrm{Zn}$ excretion.

\section{Stable isotopes}

The isotope used to label the chicken meat was prepared from ${ }^{67} \mathrm{Zn}$-enriched elemental Zn (91.9 atom \%; Technical and Optical Equipment, Edgware Road, London) dissolved in concentrated AnalaR hydrochloric acid and adjusted to $\mathrm{pH} 7.4$ with sodium bicarbonate and trisodium citrate to a final solution containing $1.84 \mathrm{mg}{ }^{67} \mathrm{Zn} / \mathrm{ml}$.

The ${ }^{70} \mathrm{Zn}$ solution injected intravenously into the subjects was prepared as zinc citrate from ${ }^{70} \mathrm{Zn}$-enriched zinc oxide $(65.51$ atom \%; Oak Ridge National Laboratory, TN, USA). The $\mathrm{ZnO}(51.5 \mathrm{mg})$ was dissolved in Aristar $\mathrm{HCl}$, evaporated to dryness, the precipitate taken up in trisodium citrate, and the solution titrated to $\mathrm{pH} 7.0$ using sodium bicarbonate. The final solution was divided into fifteen portions of $5 \mathrm{ml}$, sealed in glass ampoules, autoclaved and subjected to routine sterility testing in the Pharmacy Department of the Norfolk \& Norwich Hospital (Norwich).

\section{Absorption measurement}

A complete faecal collection was made from the time of the test meal until the carmine had been excreted, plus one further collection, as described elsewhere (Fairweather-Tait et al. 1987). Stools were stored at $-18^{\circ}$ until the completion of the study when all collections from each subject for each period were combined and prepared for analysis as in previous studies (Fairweather-Tait et al. 1989 b). Total $\mathrm{Zn}$ was determined by atomic absorption spectrophotometry (AAS) and ${ }^{67} \mathrm{Zn}$ and ${ }^{70} \mathrm{Zn}$ by thermal-ionization mass spectrometry (TIMS), as described on p. 414.

Urine was collected for $24 \mathrm{~h}$ after the test meal and a portion evaporated to dryness in a silica crucible, heated to $480^{\circ}$ for $48 \mathrm{~h}$ in a muffle furnace, and the ash taken up in concentrated $\mathrm{HCl}$ and analysed for $\mathrm{Zn}$ by AAS and ${ }^{67} \mathrm{Zn}$ and ${ }^{70} \mathrm{Zn}$ by TIMS, as described on p. 414.

Apparent absorption from the meal was calculated by deducting faecal ${ }^{67} \mathrm{Zn}$ from the administered dose, after making due allowance for naturally occurring ${ }^{67} \mathrm{Zn}$ (FairweatherTait et al. 1991). True absorption was estimated by taking into account endogenous excretion of ${ }^{67} \mathrm{Zn}$ using the faecal ${ }^{70} \mathrm{Zn}$ enrichment values obtained from the first faecal collection following the intravenous ${ }^{70} \mathrm{Zn}$ injection. As subjects did not alter their diets during the course of the study it was assumed that endogenous excretion remained constant, and the correction factor applied to both test meals for each subject was the same. The calculations were as follows:

$$
E=I-A+S,
$$


where $E$ is faecal ${ }^{67} \mathrm{Zn}(\mathrm{mg}), I$ is ${ }^{67} \mathrm{Zn}$ intake $(\mathrm{mg}), A$ is ${ }^{67} \mathrm{Zn}$ absorption (mg), and $S$ is faecal ${ }^{67} \mathrm{Zn}$ secretion $(\mathrm{mg})$.

If $S$ is $x \%$ of $A$, where $x$ is assumed to be the same values as obtained for faecal ${ }^{70} \mathrm{Zn}$ (expressed as a percentage of dose administered), then by substitution

$$
\begin{aligned}
A & =I-E+\frac{x}{100} A, \\
& =\frac{I-E}{1-x \%},
\end{aligned}
$$

and percentage true absorption from the test meal is $A / I \times 100 \%$.

\section{Faecal analysis}

Pooled faecal samples were heated in an autoclave at $0.776 \mathrm{~mm} \mathrm{Hg}$ and $121^{\circ}$ for $20 \mathrm{~min}$, freeze-dried, ground to a fine powder in a Moulinex coffee grinder (Moulinex Ltd, Coulsdon, Surrey) and passed through a $30 \mathrm{~mm}$ sieve to recover all the radio-opaque markers. After mixing in a powder homogenizer (Pascall Engineering, Crawley, Sussex) for 30 min, subsamples were taken for analysis. The total $\mathrm{Zn}$ content was determined by AAS (PU9000; Philips, Cambridge) after dry-ashing at $480^{\circ}$, using bovine liver and wheat flour as reference standards (National Bureau of Standards, Gaithersburg, MD, USA).

The isotopic enrichment of the samples was determined by TIMS (THQ; FinneganMAT GmbH, Bremen, Germany) after selective extraction of Zn (Fairweather-Tait et ail. 1989 b), as described previously (Fairweather-Tait et al. 1991).

\section{Food analysis}

Daily duplicate diet collections (solids and liquids) were homogenized in a Waring food blender (Jennings, Nottingham), made up to a known volume and a portion was freezedried. The freeze-dried powder was mixed and subsamples were analysed for $\mathrm{Zn}$ by AAS. The test meals were analysed for $\mathrm{Zn}$ and $\mathrm{Ca}$ by AAS.

\section{Phytate}

The phytate content of the wholemeal and white breads used to make the chicken sandwiches was measured, separating the phytate by the method of Harland \& Oberleas (1986). Hydrolysis of phytate eluate was carried out with sulphuric acid for $3 \mathrm{~h}$ at $140^{\circ}$ and P was determined by the method of Parker \& Peterson (1965).

\section{Statistical analysis}

Results for $\mathrm{Zn}$ absorption were tested by Student's paired $t$ test (Snedecor \& Cochran, 1967). The relationships between $\mathrm{Zn}$ intake and $\mathrm{Zn}$ absorption and excretion were examined by regression analysis using a GENSTAT program (Payne et al. 1987).

\section{RESULTS}

Mean daily Zn intakes of the subjects (measured over a $7 \mathrm{~d}$ period) on diets containing white or wholemeal bread are given in Table 1, together with their standard deviations. The overall mean for the group was 8.9 (SD 2.6$) \mathrm{mg} / \mathrm{d}$, and values ranged from 5.4 to $13.8 \mathrm{mg} / \mathrm{d}$. Although individual subjects generally followed a high, medium or low pattern of intake, where dietary patterns differed greatly from day to day the variation in $\mathrm{Zn}$ intake also fluctuated. For example, $\mathrm{Zn}$ intake by subject no. 8 was low $(4-5 \mathrm{mg} / \mathrm{d})$ for $5 \mathrm{~d}$ of the week, but higher on the other $2 \mathrm{~d}(8.2$ and $16.6 \mathrm{mg} / \mathrm{d})$. The type of bread consumed affected $\mathrm{Zn}$ 
Table 2. Total zinc, ${ }^{67} \mathrm{Zn}$, calcium and phytate content of chicken meat and bread used to make test meals*

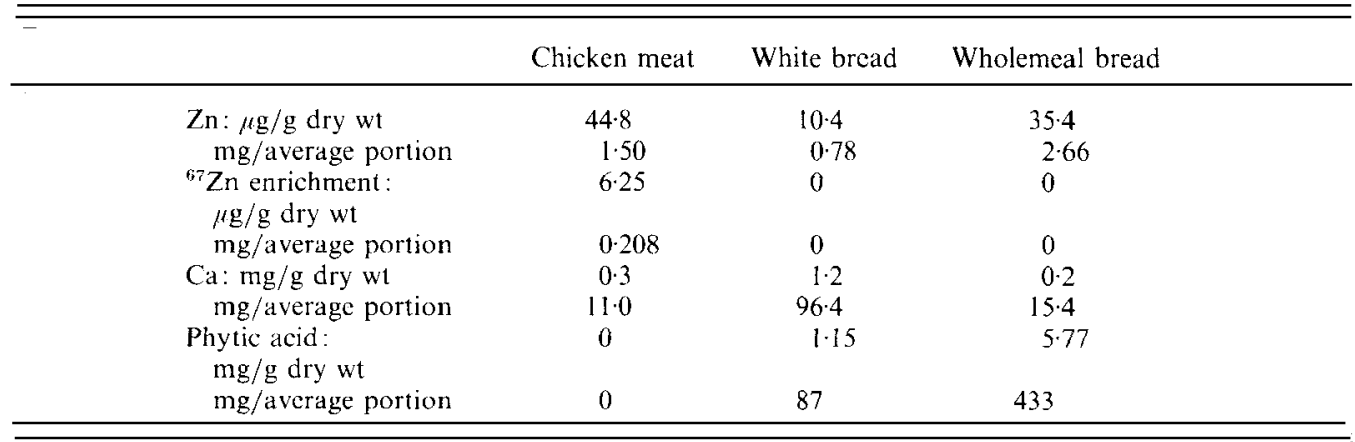

* For details of procedures, see pp. 412-414.

Table 3. Faecal and 24 h urinary excretion of intravenous ${ }^{70} \mathrm{Zn}$ administered to adult male subjects

\begin{tabular}{|c|c|c|c|c|c|}
\hline \multirow[b]{2}{*}{ Subject no. } & \multicolumn{3}{|c|}{ After the first test meal } & \multicolumn{2}{|c|}{ After the second test meal } \\
\hline & $\begin{array}{c}\text { Faecal } \\
\text { collection } \\
\text { (no. of days) }\end{array}$ & $\begin{array}{c}\text { Faeca! } \\
\text { excretion } \\
(\% \text { of dose })\end{array}$ & $\begin{array}{c}\text { Urinary } \\
\text { excretion } \\
\text { (\% of dose) }\end{array}$ & $\begin{array}{l}\text { Time interval } \\
\text { between test } \\
\text { meals (d) }\end{array}$ & $\begin{array}{c}\text { Daily excretion } \\
\text { of }{ }^{70} \mathrm{Zn}(\% \text { of } \\
\text { dose) }\end{array}$ \\
\hline 1 & 5 & $11 \cdot 0$ & $0 \cdot 2$ & 7 & $1 \cdot 0$ \\
\hline 2 & 6 & $7 \cdot 3$ & $0 \cdot 3$ & 21 & 0.5 \\
\hline 3 & 4 & $5 \cdot 2$ & $0 \cdot 3$ & 7 & $1 \cdot 5$ \\
\hline 4 & 6 & $9 \cdot 3$ & $0 \cdot 5$ & 7 & 0.7 \\
\hline 5 & 5 & $9 \cdot 6$ & $0 \cdot 5$ & 7 & 0.7 \\
\hline 6 & 5 & $9 \cdot 4$ & 0.4 & 7 & 0.8 \\
\hline 7 & 6 & $6 \cdot 4$ & $0 \cdot 4$ & 20 & $0 \cdot 1$ \\
\hline 8 & 6 & $8 \cdot 3$ & $0 \cdot 4$ & 20 & $0 \cdot 4$ \\
\hline 9 & 4 & $5 \cdot 4$ & $0 \cdot 4$ & 7 & 0.5 \\
\hline 10 & 4 & $5 \cdot 5$ & $0 \cdot 4$ & 7 & $0 \cdot 9$ \\
\hline 11 & 5 & $4 \cdot 6$ & $1 \cdot 0$ & 21 & $0 \cdot 2$ \\
\hline Mean & & $7 \cdot 5$ & $0 \cdot 4$ & & $0 \cdot 7$ \\
\hline SD & & $2 \cdot 2$ & $0 \cdot 2$ & & 0.4 \\
\hline
\end{tabular}

intake since wholemeal bread contains 2.5 times more $\mathrm{Zn}$ than white bread. The $\mathrm{Zn}$ intake on the alternative diet was calculated from a knowledge of the weight of bread consumed, and this is given in Table 1.

The $\mathrm{Zn},{ }^{67} \mathrm{Zn}, \mathrm{Ca}$ and phytate content of the chicken meat and breads used to prepare the test meals are given in Table 2 . The contribution made by margarine to the $\mathrm{Zn}$ and phytate intake is not shown as it was negligible.

Faecal and urinary excretion of the injected ${ }^{20} \mathrm{Zn}$ is given in Table 3 , expressed as a percentage of administered dose. Mean excretion was 7.5 (SD 2.2) \% of the dose in the pooled faeces collected for about $5 \mathrm{~d}$ and 0.4 (SD 0.2 ) \% of the dose in the urine collected for $24 \mathrm{~h}$ following the injection. Not all the subjects were able to participate at the same time, so the time interval between the two test meals varied from 7 to $21 \mathrm{~d}$. Daily faecal excretion of ${ }^{70} \mathrm{Zn}$ was $0.9 \% 7 \mathrm{~d}$ post injection, whereas it had fallen to $0 \cdot 3 \%$ at $20-21 \mathrm{~d}$. Urinary excretion of ${ }^{67} \mathrm{Zn}$ was negligible. 


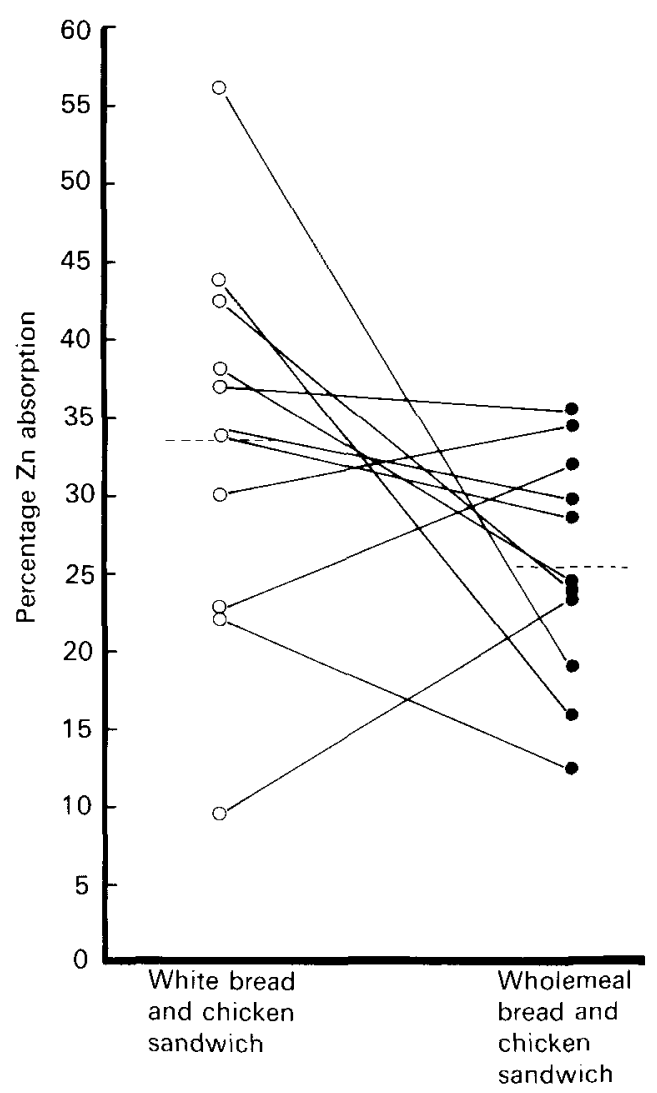

Fig. 1. Mean percentage ${ }^{67} \mathrm{Zn}$ absorption in adult men from sandwiches made from chicken meat in white $(O)$ or wholemeal (O) bread, enriched with ${ }^{67} \mathrm{Zn}$. Individual results with group means (-..--).

Individual results for ${ }^{67} \mathrm{Zn}$ absorption from the chicken-meat sandwich in white and wholemeal bread are shown in Fig. 1. There was no significant difference between the two test meals. Regression analysis of mean daily $\mathrm{Zn}$ intake (Table 1), $\mathrm{Zn}$ intake the day before (day -1$)$ and the day of the test meals (day 0 ) and $\mathrm{Zn}$ absorption showed no significant relationships. Nor was there any correlation between $\mathrm{Zn}$ intake (mean, day -1 , day 0 ) and Zn excretion.

\section{DISCUSSION}

The likely variation in $\mathrm{Zn}$ absorption rates for normal subjects consuming identical stable isotopically labelled test meals on two occasions whilst consuming the same dietary intake of $\mathrm{Zn}$ has not yet been firmly established. Undoubtedly there are fluctuations, as described for example by Solomons et al. (1982) who found the mean $\mathrm{Zn}$ absorption from replicate ${ }^{70} \mathrm{Zn}$-labelled meals given on two occasions to be 32 (SD 9 ) and 38 (SD 4) \% in four subjects. Thus, small differences in absorbability of $\mathrm{Zn}$ from foods may be obscured owing to the 'noise' factor. This is a problem common to most studies of mineral bioavailability and is generally addressed by using a large enough group of subjects to test for differences at the appropriate level of significance. In the present study the difference between the two test meals was not statistically significant, although eight of the eleven subjects had a lower percentage ${ }^{67} \mathrm{Zn}$ absorption from the wholemeal-bread sandwich. 
Fractional $\mathrm{Zn}$ absorption has been shown to be higher from white than wholemeal bread (Sandstrom et al. 1980), and this is thought to be related to the very different levels of phytate (Lonnerdal, 1989). However, wholemeal bread contains approximately three times more $\mathrm{Zn}$ than white bread, and $\mathrm{Zn}$ absorption is dose-dependent (Fairweather-Tait, 1988; Fairweather-Tait \& Southon, 1989). Therefore, despite a fall in fractional absorption with increasing dose, absolute absorption may in fact rise. For example, Sandstrom et al. (1980) found a higher absolute absorption of $\mathrm{Zn}$ from wholemeal than white bread, but when they attempted to eliminate the dose-response effect by adding zinc chloride to the white bread there was a higher absorption from white than wholemeal bread.

The amount of $\mathrm{Ca}$ and phytate in a meal undoubtedly influences $\mathrm{Zn}$ bioavailability (Ellis et al. 1987). Current literature suggests that the critical values for phytate: $\mathrm{Zn}$ and phytate $\times \mathrm{Ca}: \mathrm{Zn}$ millimolar ratios are $>15$ and $>200$ respectively (Ferguson et al. 1989). In the present study the phytate: $\mathrm{Zn}$ and phytate $\times \mathrm{Ca}: \mathrm{Zn}$ ratios in the test meals were 1.95 and 6.55 for the white-bread sandwich and 6.1 and 6.46 for the wholemeal-bread sandwich respectively. The results of the present study provide further confirmation that $\mathrm{Zn}$ absorption is not reduced in the presence of low ratios, as found in sandwiches containing meat which is a reasonably rich source of $\mathrm{Zn}$.

Protein also modifies the bioavailability of $\mathrm{Zn}$ from foods (Solomons, 1982). Sandstrom et al. (1980) used ${ }^{65} \mathrm{Zn}$ to label extrinsically meals based on bread and demonstrated an enhancing effect of beef, cheese and egg on $\mathrm{Zn}$ absorption from bread in human subjects. In a more recent study using similar techniques (Sandstrom et al. 1987) the absorption of $\mathrm{Zn}$ from a meal of chicken plus white (but not wholemeal) bread was measured and found to be $46.1 \%$, equivalent to an absolute value of $0.565 \mathrm{mg} \mathrm{Zn}$. The mean $\mathrm{Zn}$ absorption from the chicken sandwich in white bread in the present study was $33.6 \%$, which is equivalent to $1.47 \mathrm{mg} \mathrm{Zn}$. The latter value is somewhat higher than that of Sandstrom et al. (1987) because of the added (extrinsic) $\mathrm{Zn}$ isotope which increased the $\mathrm{Zn}$ concentration of the test meal. Mean absorption from the wholemeal-bread sandwich was lower (albeit not statistically different) at $25.4 \%$, which was equivalent to $1.59 \mathrm{mg} \mathrm{Zn}$. Thus, the higher $\mathrm{Zn}$ intake associated with wholemeal-bread more than compensated for the lower percentage absorption.

The previously mentioned calculations depend on the assumption that the added (extrinsic) isotopic label fully exchanges with endogenous $\mathrm{Zn}$ in the meal. The validity of this assumption is questionable. Gallaher et al. (1988) found no difference in absorption by adults given beef labelled intrinsically and extrinsically with ${ }^{65} \mathrm{Zn}$. Using stable isotopes, Flanagan et al. (1985) found no difference in intrinsically and extrinsically labelled turkey meat, but Janghorbani et al. (1982) found consistently lower absorption from the extrinsic than intrinsic label in chicken meat. Our own experience with chicken is that the extrinsic label closely models the intrinsic label, but exchange is not $100 \%$ (Fairweather-Tait et al. 1991). However, the behaviour of the extrinsic and intrinsic labels was closer in chicken meat than any of the other foods we tested. When more than one food is given, the isotope must exchange to some extent with all the $\mathrm{Zn}$ present in the meal. Preliminary results from our wheat studies again indicate incomplete exchange of extrinsic and intrinsic label, but with respect to $\mathrm{Zn}$ absorption the food effect far outweighs the labelling effect. In the present study, for reasons already stated, the quantity of extrinsic label in each meal $\left(2 \cdot 106 \mathrm{mg}{ }^{67} \mathrm{Zn}\right)$ far outweighed the amount of intrinsic label $\left(0.208 \mathrm{mg}{ }^{67} \mathrm{Zn}\right)$. Thus, the absorption measurements are primarily measurements from extrinsically-labelled material. However, since the behaviour of the extrinsic isotopic label has been shown to give a good indication of the movement of endogenous $\mathrm{Zn}$, and because the study was designed as a direct comparison between two meals similarly labelled, we believe that the method of labelling did not prejudice the results nor the validity of the conclusions reached. 
The use of intravenously administered ${ }^{10} \mathrm{Zn}$ to quantify the loss of endogenous $\mathrm{Zn}$ was based on a method devised to measure true $\mathrm{Ca}$ absorption from foods (Fairweather-Tait et al. 1989a). This technique assumes that the intravenous $\mathrm{Zn}$ is handled in the same manner as the absorbed ${ }^{67} \mathrm{Zn}$. However, it is not possible to mimic gastrointestinal $\mathrm{Zn}$ absorption, which takes place over a varying time period of several hours after ingestion of a test food (Valberg et al. 1985). Nor is it possible to validate the assumption that the two modes of administered $\mathrm{Zn}$ are handled in the same way. It is, of course, important not to perturb $\mathrm{Zn}$ metabolism; immediately after infusion the plasma $\mathrm{Zn}$ will be equilibrating with the very rapidly exchanging body pools, with enrichment falling in an exponential manner. We used a dose of $1.5 \mathrm{mg} \mathrm{Zn}$ (as ${ }^{70} \mathrm{Zn}$ ) and were reluctant to give a very much smaller dose because of uncertainty about the rate of excretion and the consequent difficulties of detecting and quantifying small amounts of isotope. In fact, only $7.5 \%$ of the intravenous dose was excreted in the faeces collected 4-6 d post injection and $0.4 \%$ in the urine collected $24 \mathrm{~h}$ post injection, which indicates that plasma capacity for $\mathrm{Zn}$ was not exceeded and that the intravenous ${ }^{70} \mathrm{Zn}$ was rapidly moved into body pools. The intravenous dose of $\mathrm{Zn}$ was in fact similar to the amount of $\mathrm{Zn}$ absorbed from the test meal, i.e. $1.5-1.6 \mathrm{mg}$, albeit over a different time interval.

When endogenous losses are small, as found with low $\mathrm{Zn}$ intakes (Jackson et al. 1988), there is little difference between apparent $\mathrm{Zn}$ absorption (calculated as the difference between intake and excretion) and true $\mathrm{Zn}$ absorption. In the present study, the habitual $\mathrm{Zn}$ intakes of the subjects were not particularly high (mean $8.9 \mathrm{mg} / \mathrm{d}$ ), and perhaps as a consequence of this the ${ }^{10} \mathrm{Zn}$ excretion was fairly low. Apparent mean $\mathrm{Zn}$ absorption from the white-bread sandwich was 31.1 (SD 11.8$) \%$ and from the wholemeal-bread sandwich 23.5 (SD 6.7) \%, which is a $7 \%$ underestimate of true absorption. No allowance was made for urinary losses of isotopes in any of the calculations because there was no measurable enrichment with ${ }^{\circ} \mathrm{Zn}$, and the ${ }^{71} \mathrm{Zn}$ was considered to make a negligible contribution to the total. It was interesting to note the prolonged faecal excretion of ${ }^{70} \mathrm{Zn}$. However, since the stool collections were bulked before analysis, we could not make any detailed deductions about the rate of fall over time.

In conclusion, it would appear from the results of the present study that $\mathrm{Zn}$ absorption from a chicken-meat sandwich was not adversely affected by substituting wholemeal for white bread. True $\mathrm{Zn}$ absorption, measured using a double-label isotope technique, was $7 \%$ higher than apparent absorption (intake minus faecal excretion) in male subjects whose mean habitual $\mathrm{Zn}$ intake was $8.9 \mathrm{mg} / \mathrm{d}$.

This work was partly supported by the Ministry of Agriculture, Fisheries and Food. The authors thank Mrs Jacqui Cook for assistance with the chickens and Mr Martin Callam for preparing the isotope for injection.

\section{REFERENCES}

Ellis, R., Kelsay, J. L., Reynolds, R. D., Morris. E. R., Moser, P. B. \& Frazier, C. W. (1987). Phytate : zinc and phytate $\times$ calcium: zinc millimolar ratios in self-selected diets of Americans, Asian Indians, and Nepalese. Journal of the American Dietetic Association 87, 1043-1047.

Fairweather-Tait, S. J. (1988). Zinc in human nutrition. Nutrition Research Reviens 1, 23--37.

Fairweather-Tait, S. J., Fox, T. E.. Wharf, S. G.. Eagles, J., Crews, H. \& Massey, R. (1991). Apparent zinc absorption by rats from foods labelled intrinsically and extrinsically with "' $\mathrm{Zn}$. British Journal of Nutrition 66 , 65-71.

Fairwcather-Tait, S. J., Johnson, A., Eagles. J., Ganatra. S., Kenncdy, H. \& Gurr, M. I. (1989a). Studies on calcium absorption from milk using a double-label stable isotope technique. British Journal of Nutrition 62. $379 \cdot 388$.

Fairweather-Tait, S. J., Minski, M. J. \& Singh, J. (1987). Nonradioisotopic method for measuring iron absorption from a Gambian meal. American Journal of Clinical Nutrition 46, 844-848. 
Fairweather-Tait, S. J., Portwood, D. E., Symss, L. L., Eagles, J. \& Minski, M. J. (1989b). Iron and zinc absorption in human subjects from a mixed meal of extruded and nonextruded wheat bran and flour. American Journal of Clinical Nutrition 49, 151 155.

Fairweather-Tait, S. J. \& Southon, S. (1989). Studies of iron:zinc interactions in adult rats and the effect of iron fortification of two commercial infant weaning products on iron and zinc status of weanling rats. Journal of Nutrition 119, 599-606.

Ferguson, E. L., Gibson, R. S., Thompson, L. U. \& Ounpuu, S. (1989). Dietary calcium, phytate, and zinc intakes and the calcium, phytate, and zinc molar ratios of the diets of a selected group of East African children. American Journal of Clinical Nutrition 50, 1450-1456.

Flanagan, P. R., Cluett, J., Chamberlain, M. J. \& Valberg, L. S. (1985). Dual-isotope method for determination of human zinc absorption: the use of a test meal of turkey meat. Journal of Nutrition 115, 111-122.

Fox, T. E., Fairweather-Tait, S. J., Eagles, J. \& Wharf, S. G. (1991). Intrinsic labelling of different foods with stable isotopes of zinc $\left({ }^{67} \mathrm{Zn}\right)$ for use in bioavailability studies. British Journal of Nutrition 66, 57-63.

Gallaher, D. D., Johnson, P. E., Hunt, J. R., Lykken, G. 1. \& Marchello, M. J. (1988). Bioavailability in humans of zinc from beef: intrinsic vs extrinsic labels. American Journal of Clinical Nutrition 48, 350-354.

Harland, B. F. \& Oberleas, D. (1986). Anion-exchange method for determination of phytate in foods: collaborative study. Journal of the Association of Official Analytical Chemists 69, 667-670.

Jackson, M. J., Giugliano, R., Giugliano, L. G., Oliveira, E. F., Shrimpton, R. \& Swainbank, I. G. (1988). Stable isotope metabolic studies of zinc nutrition in slum-dwelling lactating women in the Amazon valley. British Journal of Nutrition 59, 193203.

Janghorbani, M., Istfan, N. W., O'Pagounes, J., Steinke, F. H. \& Young, V. R. (1982). A bsorption of dietary zinc in man: comparison of intrinsic and extrinsic labels using a triple stable isotope method. American Journal of Clinical Nutrition 36, 537-545.

Lonnerdal, B. (1989). Food and dietary factors influencing levels and bioavailability of trace elements. In Nutrient Availability: Chemical and Biological Aspects, pp. 131-143 [D. Southgate, I. Johnson and G. R. Fenwick, editors]. Cambridge: Royal Society of Chemistry.

Mason, P. M., Judd, P. A., Fairweather-Tait, S. J., Eagles, J. \& Minski, M. J. (1990). The effect of moderately increased intakes of complex carbohydrates (cereals, vegetables and fruit) for 12 weeks on iron and zinc metabolism. British Journal of Nutrition 63, 597611

Navert, B., Sandstrom, B. \& Cederblad, A. (1985). Reduction of the phytate content of bran by leavening in bread and its effect on zinc absorption in man. British Journal of Nutrition 53, 47-53.

Parker, F. \& Peterson, N. F. (1965). Quantitative analysis of phospholipids and phospholipid fatty acids from silica gel thin-layer chromatography. Journal of Lipid Reseurch 6, 455-460.

Payne, R. W., Lane, P. W., Ainsley, A. E., Bicknell, K. E., Digby, P. G. N., Harding, S. A., Leech, P. K.. Simpson, H. R., Todd, A. D., Verner, P. J., White, R. P., Gower, J. C., Tunnicliffe Wilson, G. \& Paterson. L. J. (1987). Genstat 5 Reference Manual. Oxford: Clarendon Press.

Sandstrom, B., Arvidsson, B., Cederblad, A. \& Bjorn-Rasmussen, E. (1980). Zinc absorption from composite meals. I. The significance of wheat extraction rate, zinc, calcium, and protein content in meals based on bread. American Journal of Clinical Nutrition 33, 739-745.

Sandstrom, B., Davidsson, L., Kivisto, B., Hasselblad, C. \& Cederblad, A. (1987). The effect of vegetables and beet fibre on the absorption of zinc in humans from composite meals. British Journal of Nutrition 58, 49.57.

Snedecor, G. W. \& Cochran, W. G. (1967). In Statistical Methods, pp. 91 100. Ames, IA: Iowa State University Press.

Solomons, N. W. (1982). Biological availability of zine in humans. American Journal of Clinical Nutrition 35, 1048- 1075.

Solomons, N. W., Janghorbani, M., Ting. B. T. G., Steinke, F. H., Christensen, M., Bijlani, R., Istfan, N. \& Young, V. R. (1982). Bioavailability of zinc from a diet based on isolated soy protein : application in young men of the stable isotope tracer, ${ }^{70} \mathrm{Zn}$. Journal of Nutrition 112, 1809-1821.

Valberg, L. S, Flanagan, P. R., Brennan J. \& Chamberlain, M. J. (1985). Does the oral zinc tolerance test measure zine absorption? American Journal of Clinical Nutrition 41, 37-42. 